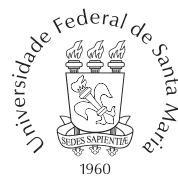

DOI: http://dx.doi.org/10.5902/2236672536866

Recebido em: 14/02/2019. Aprovado em: 03/08/2019.

\title{
A REPRESENTAÇÃO DA CEILÂNDIA E DOS CEILANDENSES NO CINEMA DE ADIRLEY QUEIRÓS.*
}

\author{
THE REPRESENTATION OF CEILANNDIA AND ITS \\ INHABITANTS IN THE CINEMA OF ADIRLEY QUEIRÓS. \\ LA REPRESENTATION DE CEILANDIA ET SES \\ HABITANTS DANS LE CINEMA D'ADIRLEY QUEIROS. \\ LA REPRESENTACIÓN DE CEILÂNDIA Y SUS \\ HABITANTES EN EL CINE DE ADIRLEY QUEIRÓS. \\ Carlos Eduardo da Silva Ribeiro** \\ (iD) https://orcid.org/0000-0003-4337-382X
}

\begin{abstract}
RESUMO: O trabalho analisa a obra de Adirley Queirós, diretor de cinema radicado na Ceilândia. Maior cidade-satélite de Brasília, locação e meta-texto desse conjunto de filmes, a Ceilândia surgiu de um dos processos de remoção da população pobre/ não-branca do Plano Piloto para a sua periferia durante a ditadura civil-militar. Essa forma de segregação aplicada no Distrito Federal, que imbrica classe social e racialização, contradisse os princípios de horizontalidade do modernismo que inspirou o projeto de Brasília (Holston, 1993; Gouvêa, 1998), e é abordada no cinema de Queirós a partir do olhar daqueles expelidos desse projeto. O conjunto de filmes abordado transita entre regimes documentais e ficcionais, por vezes problematizando essas fronteiras; simultaneamente referindo a certa realidade social vivenciada pelos sujeitos representados e especulando acerca dos espaços, das diferenças e identidades de Brasília e Ceilândia, esporadicamente exacerbando os efeitos dessa diferenciação através de elementos de ficção-científica. Partindo do paradigma dos Estudos Culturais, o trabalho se centra na construção simbólica da Ceilândia e de seus habitantes no cinema de Queirós,

\footnotetext{
* Agradeço a Mathias Fauver e Betina Dias Torriani pela ajuda com as traduções para o francês e inglês respectivamente.

*** Mestre em Sociologia pela Universidade Federal de Pelotas (UFPel); doutorando em Comunicação na Universidade Federal do Rio Grande do Sul (UFRGS), Porto Alegre, RS, Brasil; E-mail: dudaribeirodudaribeiro@gmail.com
} 
A representação da Ceilândia e dos ceilandenses no cinema de Adirley Queirós.

considerando as dimensões formais desses filmes em seu diálogo com o contexto sócio-histórico em que se ambientam.

Palavras-chave: Ceilândia/DF; Adirley Queirós; Cinema brasileiro; ficção-científica; Identidade e diferença.

ABSTRACT: The paper analyzes the work of Adirley Queirós, film director settled in Ceilândia, the biggest satellite-city of Brasilia, location and meta-text of his movies. Ceilândia rises from the resettlement of the poor/colored population from the Pilot Plan to its surroundings during the civil-military dictatorship. This kind of segregation, that imbricates social class and racialization, contradicts the principles of horizontality from the modernism wich inspired the design of Brasilia (Holston, 1993; Gouvêa, 1998), and is approached on Queirós' cinema through the glance of those expelled from it. The set of movies here analyzed transits between documental and fictional regims, sometimes problematizing these borders; simultaneously refering to a certain social "reality" experienced by the represented subjects and speculating about these spaces, identities and differences of Brasilia and Ceilândia, sporadically exacerbating the effects of this differentiation trough sci-fi elements. Starting from the paradygm of the Cultural Studies, the papers focuses on the simbolic construction of Ceilândia and it's inhabitants on the Queirós' work, considering the formal dimensions of these films in it's dialog with the sociohistorical context in which these narratives fit in.

Keywords: Ceilândia/DF; Adirley Queirós; Science fiction; Brazilian cinema; Identity and difference.

RÉSUMÉ: Ce travail analyse l'oeuvre d'Adirley Queirós, réalisateur brésilien basé à Ceilandia, la plus grande ville-satellite de Brasilia, qui sert à la fois de location et de fil conducteur dans ses films. La création de Ceilandia est le fruit du processus d'éloignement de la population pauvre/noire vers la périphérie urbaine lors du Plano Piloto - le fameux projet d'urbanisation et de modernisation de Brasilia élaboré par Lucio Costa en 1957 - à l'époque de la dictature civile-militaire. Cette forme de ségrégation, imbriquant classification sociale et racialisation, contredit les principes d'horizontalité du modernisme qui avait inspiré le projet de Brasilia (Holston, 1993; Gouvêa, 1998), est abordée dans le cinéma de Queirós à partir du regard des exclus. L'ensemble des films analysés ici transite entre le cadre du documentaire et celui de la fiction, et on y retrouvera souvent une problématisation de ces frontières, faisant référence simultanément à une certaine "réalité" sociale vécue 
par les sujets représentés et spéculant autour des espaces, des différences et des identités de Brasilia et de Ceilandia et même exagérant occasionnellement les effets de cette différentiation avec l'utilisation d'éléments de science fiction. Partant de la perspective de l'Étude Culturelle, l'article se centre sur la construction symbolique de Ceilandia et de ses habitants dans le cinéma de Queirós, en considérant les dimensions formelles de ces films, mais aussi leur dialogue avec le contexte socio-historique qui sous-tend les différents récits.

Mots-clefs: Ceilândia/DF; Adirley Queirós; Cinéma brésilien, Science fiction; Identité et différence.

RESUMEN: Este trabajo analiza la obra de Adirley Queirós, director de cine con sede en Ceilândia. La ciudad satélite más grande de Brasilia, ubicación y metatexto de este conjunto de películas, Ceilândia surgió de uno de los procesos de remoción de la población pobre/no blanca del Plano Piloto a su periferia mientras la dictadura civil-militar. Esta forma de segregación aplicada en el Distrito Federal, que imbuye la clase social y la racialización, contradice los principios del horizontalismo del modernismo que inspiraron el proyecto Brasilia (Holston, 1993; Gouvêa, 1998), y se aborda en el cine de Queirós desde la mirada. los expulsados de este proyecto. El conjunto de películas abordadas transita entre regímenes documentales y ficticios, a veces problematizando estos límites; refiriéndose simultáneamente a cierta realidad social experimentada por los sujetos representados y especulando sobre los espacios, diferencias e identidades de Brasilia y Ceilândia, exacerbando esporádicamente los efectos de esta diferenciación mediante elementos de ficción científica. Partiendo del paradigma de los Estudios Culturales, el trabajo se enfoca en la construcción simbólica de Ceilândia y sus habitantes en el cine Queirós, considerando las dimensiones formales de estas películas en su diálogo con el contexto sociohistórico en el que se encuentran.

Palabras clave: Ceilândia / DF; Adirley Queirós; Cine brasileño; ficción científica; Identidad y diferencia.

\section{INTRODUÇÃO}

Adirley Queirós é um cineasta de Ceilândia/DF. Nascido em Goiás, filho de camponeses, sua família mudou-se para Brasília e, aos seus 3 anos de idade, para a Ceilândia. Após ter cumprido carreira como jogador de futebol em clubes da região, ingressou no curso 
de Cinema da UnB aos 28 anos, graduando-se sete anos depois. Seu filme mais antigo e trabalho de conclusão de curso de graduação é o documentário Rap, o canto da Ceilândia (2005), o qual ganhou pelo menos 13 prêmios em festivais de cinema no Brasil, dentre os quais dois de Melhor Curta no tradicional Festival de Brasília, um pelo júri oficial e outro pelo júri popular.

Logo no começo desse curta-metragem, um trecho de entrevista soa em off-screen enquanto vemos uma imagem panorâmica na Ceilândia: "Isso aqui é uma história de sangue, suor e lágrimas". Os depoimentos e raps que compõem a trilha sonora são de Mc's locais, que nos apresentam oralmente os temas da violência cotidiana na cidade, a convivência com o tráfico de drogas, tiros, armas, abusos de poder policial, falta de representatividade política, etc. Ainda no início do filme vemos fotografias em preto e branco da chegada das primeiras famílias na Ceilândia, enquanto as entrevistas detalham o processo.

A Campanha de Erradicação de Invasões (CEI), projeto governamental de 1969 voltado a combater a favelização de Brasília, batiza a partir de sua sigla a cidade da Ceilândia'. A Campanha foi executada pela Novacap (Companhia Urbanizadora da Nova Capital) e consistiu em erradicar 82 mil pessoas (Gouvêa, 1998, p.82) - em grande medida as famílias dos trabalhadores braçais nordestinos ${ }^{2}$ que construíram a Capital Federal durante o governo JK - e realoca-las a aproximadamente 30 quilômetros da capital, na cidade que teve como marco zero o dia de 27 de março de 1971. Os rappers afirmam em entrevistas no filme que esse povo "carente" teria sido arrancado "à força [...] da vila do IAPI" e jogado numa Ceilândia sem água nem luz. X, um desses rappers, relata que inicialmente na Ceilândia os banheiros eram "fossas" e que os primeiros moradores precisavam tomar banho

1 A Campanha da Erradicação das Invasões não inaugura a segregação no Distrito Federal. Conforme Gouvêa (1998, p.82), antes da inauguração de Brasília, "já em 1958, foi criada a cidade-satélite de Taguatinga, distante cerca de vinte e cinco quilômetros dos locais de trabalho, para abrigar a população trabalhadora removida de favelas próximas ao Plano-Piloto". Após a inauguração o processo de remoção se tornou sistemático nos vários governos que se seguiram. "[...] a partir do momento em que as obras foram ficando prontas, o candango era compelido a deixar a capital, nos sucessivos programas de retorno de migrantes implementados a partir de 1963, ou eram removidos para localidades distantes do Plano-Piloto, entre doze e cinquenta quilômetros, em assentamentos desenvolvidos a partir de 1958 e intensificados na década de 60, que originaram e/ou expandiram as várias cidades-satélites.”.

2 Na década de 1950, uma seca devastou o nordeste e forçou "dezenas de milhares de pessoas a ir para o sul, especialmente para Brasília" (Holston, 1993, p.223), o que explica parcialmente o predomínio desta população dentre os trabalhadores da região. 
de bacia. A caixa d'água da Ceilândia, cartão-postal e parte central da bandeira daquela região administrativa, é considerada o "símbolo de uma história de luta [...] a sobrevivência da gente": um resultado do esforço da comunidade para superar as adversidades imbricadas na precariedade das condições a que foram relegados pelos representantes legais. A cidade hoje tem cerca de meio milhão de habitantes ${ }^{3}$, sendo a maior região administrativa do Distrito Federal.

O curta-metragem Rap, o canto da Ceilândia (2009) carrega já no título um trocadilho que liga o "cantar" dos rappers locais ao "canto" territorial que é a periferia. A relação umbilical entre Ceilândia e Brasília é apresentada no filme a partir da perspectiva dos ceilandenses, buscando valorizar essa população através das suas manifestações culturais (o rap principalmente) e simultaneamente explicitando, através de seus depoimentos e rimas, uma crise de reconhecimento em torno do rap e da periferia. No encerramento do documentário, Marquim da Tropa, um rapper cadeirante, comenta para a lente de Queirós: "Brasília eu enxergo assim: um muro que separou os pobre dos rico [...]", enfatizando o caráter segregacionista do arranjo urbano do Distrito Federal. O filme se conclui com a seguinte frase do mesmo personagem: "Eu não moro em Brasília, eu moro na Ceilândia". A diferença territorial como representada, separando "os pobre dos rico", pode nos remeter ao teórico Stuart Hall (2014, p.109), quando propõe que as identidades se fundam a partir da "marcação da diferença e da exclusão", ou seja, se situam em conflito e relacionalmente. A relação Brasília/Ceilândia recorre nos filmes de Queirós e é abordada já de forma enfática desde esta primeira produção. A Ceilândia, que tem como momento de origem a própria expurgação de seus cidadãos de Brasília, como representada por Queirós não pode ser compreendida sem referências à capital, cuja história oficial posiciona os sujeitos numa ordem dos acontecimentos e se entrelaça nos filmes às histórias cotidianas.

Rap, o canto da Ceilândia (2009) marca a fundação simbólica do Coletivo de Cinema da Ceilândia (Ceicine), no qual Queirós ocupa uma posição de destaque e a partir de onde desenvolve sua

3 Segundo a Pesquisa Distrital por Amostra de Domicílios (PDAD) de 2015, a população da Ceilândia era de 489.351 habitantes. Disponível online em: < https://bit.ly/2TWFUHl >, acesso em 18/1/19. 
filmografia. Sua produção carrega um olhar crítico para aspectos que remetem à cidade, de forma que a escolha enunciada no título do trabalho por percorrer com ênfase a representação das diferenças socioespaciais não é arbitrária. De maneira articulada à segregação urbana, os filmes tematizam problemas e demandas de grupos ceilandenses específicos, como os rappers no primeiro curta-metragem: são apresentados, ao longo dos filmes posteriores, serralheiros em desacordo com o patrão, jogadores de futebol mal pagos de pequenos clubes regionais, políticos em precárias campanhas eleitorais, jovens negros vítimas de violência policial, etc. Revelam-se nessa filmografia categorias de diferenciação diversas - como "raça", "origem", "gênero", "capacitismo" e "classe" -, que, na forma com que se conectam contextualmente, dão nuances à relação socioespacial como vivenciadas. Logo, de forma correlata ao problema de como os filmes representam a cidade e a maneira com que esses sujeitos experimentam as diferenças em termos de segregação urbana, investiremos em uma leitura interseccional ${ }^{5}$ das diferenças como representadas nos filmes de Queirós.

Filiado ao campo de investigação dos Estudos Culturais ${ }^{6}$, o trabalho consiste em grande medida em análises fílmicas. Inexiste na perspectiva adotada uma teoria central que seja baseada em alguma determinação a princípio e que estruture as análises: o "contextualismo radical" (Restrepo, 2012, p.133) dos Estudos Culturais leva

4 Quando falando de raça, tratamos da construção cultural e simbólica associada ao fenótipo, a elementos culturais étnicos e ao racismo. O sentido biológico das raças humanas tem sido desacreditado desde o fim da $2^{\text {a }}$ Guerra Mundial, a partir de uma série de contribuições científicas, em especial da antropologia (Guimarães, 2002).

5 A perspectiva interseccional é uma ferramenta de investigação que aponta para a articulação de formas múltiplas de diferenças e desigualdades, reconstituindo-as contextualmente. Primeiramente elaborada na década de 1990 pela advogada negra estadunidense Kimberlé Crenshaw, a noção de interseccionalidades buscava capturar simultaneamente as consequências de duas ou mais formas de subordinação e mostrar como diferentes formas de opressão estruturais se articulam. Contudo, conforme Adriana Piscitelli (2008, p.267) "As leituras críticas sobre interseccionalidade consideram essa leitura de Crenshaw expressiva de uma linha sistêmica, que destaca o impacto do sistema ou [d]a estrutura sobre a formação de identidades". Avtar Brah, em uma reformulação construcionista das interseccionalidades, pensa as diversas categorias como uma articulação de diferenças que se referem a desigualdades tanto quanto a possibilidades de agência, abrindo espaço para uma teoria da ação que vem a calhar na análise fílmica.

6 Seu surgimento é comumente relacionado ao Centre for Contemporary Culture Studies (19641980), na Birmingham University, Inglaterra. Esse núcleo marginal de pesquisa na década de 1960 expandiu-se e internacionalizou-se como programa de investigação principalmente a partir da década de 1980. Conforme Robert Stam (2013, p.248): "Uma genealogia mais internacional e difusa dos estudos culturais poderia ser vinculada ao trabalho de figuras como Roland Barthes na França, Leslie Fiedler nos Estados Unidos, Frantz Fanon na França e no norte da África e C.R.L. James no Caribe, todos ativos na década de 1950". 
a que sejam valorizadas as especificidades locais e as contingências que podem variar a significação de um objeto, símbolo, conceito ou prática, impedindo a universalização e cristalização de uma abordagem aprioristicamente. De maneira correlata, na bibliografia relacionada à análise fílmica recorre a impossibilidade da definição de um método universal (Aumont e Marie, 2011; Stam, 2013, p.19). Considerando as relações mutuamente constitutivas entre o texto e seu contexto, tratamos analiticamente o filme como um meio de expressão original com "determinada combinação de imagens, sons, tempos, espaços e corpos” (Guimarães e Guimarães, 2011, p.83) organizadas em seu interior; um espaço multidimensional onde uma diversidade de símbolos funde-se e entra em conflito, em diálogo com o social. Dada a natureza qualitativa da metodologia, trabalhamos com um recorte frente às quase 6 horas de extensão total desses filmes, no qual buscamos apreender elementos e símbolos que mais significativamente orientem-se para a questão de pesquisa: como o cinema de Adirley Queirós representa a Ceilândia e suas relações e diferenças com Brasília, tanto em termos espaciais quanto no que trata às suas respectivas populações e manifestações culturais. Para tanto, de maneira articulada à análise de sua filmografia, lançamos mão de outros arquivos como entrevistas com o diretor (Dalpizzolo, 2012; Suppia e Gomes, 2014) e análises prévias de seus filmes (Cantuaria, Chacon e Guimarães, 2015; Isaías, 2017; Lima 2016; Mesquita, 2015; Oliveira e Maciel, 2018; Saboia e Sandoval, 2012; Suppia, 2015), a serem mobilizados ao longo do texto conforme prudentes.

O presente artigo contribui com uma análise de como esses filmes estão atravessados por disputas sócio-simbólicas e como representam essas disputas que lhes atravessam; e de como as narrativas de Queirós contam a história do Distrito Federal a partir da ênfase em vozes segregadas. Seu cinema integra um período da cinematografia brasileira marcado pela implementação de uma série de medidas de financiamento público-privadas e pela expansão das possibilidades de realização e enunciação. De forma correlata, em uma escala global, desde a década de 1990 o advento das tecnologias digitais no audiovisual e a disseminação dos computadores pessoais horizontalizaram o acesso aos equipamentos e processos inerentes 
à produção fílmica. No Brasil, teóricos têm referido como pós-retomada (Barone, 2011, p.917) o período que compreende desde 2003 até as recentes turbulências no Governo Federal. Nesse período, a forte atuação da Ancine atrelada ao Ministério da Cultura - dentre outros fatores - possibilitaram a revitalização do mercado cinematográfico e do parque exibidor e um melhoramento significativo nas condições de realização fílmica e acesso a financiamento, bem como de maior reconhecimento nacional e internacional das produções em relação às décadas imediatamente anteriores ${ }^{7}$. No que toca a Queirós, cineasta inserido nesse contexto, a expansão das universidades federais também favorece a factibilidade do seu cinema e de sua emergência como diretor, vista a graduação do ceilandense na UNB.

De forma geral, os filmes serão aqui analiticamente tomados como formas de representação e agenciamento ${ }^{8}$ de diferenças através da construção de identidades provisórias por parte dos personagens/ sujeitos envolvidos tanto quanto por parte das narrativas como um todo. Para tanto, o texto se separa em dois capítulos: um primeiro que se foca na construção fílmica da Ceilândia enquanto história e ambiente socioespacial e dos moradores/personagens, indo de Rap, $o$ canto da Ceilândia (2005), passando por Fora de Campo (2009), Dias de Greve (2012) e A cidade é uma só? (2012), até Branco sai, preto fica (2014); e um segundo capítulo que analisa a mescla de procedimentos ficcionais e documentais em A cidade é uma só? (2012) e especialmente em Branco Sai, Preto Fica (2014) e Era uma vez Brasília (2017). Assim, analisaremos as representações plurais da Ceilândia e de sua população feitas por Queirós, transversalmente às transformações do diretor no trato com a linguagem fílmica, considerando o movimento feito através desses filmes que parte da busca pela apreensão do "real" através da documental" para a disposição de ficcionalizações

7 Em 1990 ocorreu uma súbita ruptura na produção de filmes no Brasil devido à desestatização da Embrafilme. Novas políticas para o setor só passaram a tomar corpo após a criação da ANCINE (Agência Nacional do Cinema) em 2001, através da Medida Provisória n. ${ }^{\circ} 2.228$-1, na presidência de Fernando Henrique Cardoso. O ano de 2003, quando a ANCINE é vinculada ao Ministério da Cultura, marca a transição para a fase de "pós-retomada" do cinema brasileiro.

8 Por "agência", compreender a parte ativa da ação, que, por sua vez, não pode ser pensada de forma separada das injunções da vida social. Para Brah, os agenciamentos são espaço para a reconstrução das diferenças: o sujeito é efeito de discursos, instituições e práticas, mas "tanto consciente como inconscientemente" desempenha e ressignifica as "posições em que está situado e investido" (2006, p.374). 9 O Dicionário teórico e crítico de cinema (Aumont e Marie, 2003, p.86) propõe que o documentário "tem, quase sempre, um caráter didático ou informativo, que visa, principalmente, restituir as aparências da realidade, mostrar as coisas e o mundo tais como eles são". Contudo, os mesmos 
que ativamente mesclam situações encenadas e cenários fictícios com as experiências dos sujeitos e o quotidiano da cidade.

\section{A CONSTRUÇÃO E ENCENAÇÃO DA CEILÂNDIA}

No presente tópico, realizaremos uma análise dos cinco primeiros filmes de Adirley Queirós, focando em suas formas de representar a cidade da Ceilândia e seus habitantes. Essas produções, engendradas por realizadores neófitos, podem ser consideradas uma série de olhares sobre a Ceilândia, onde a noção de pertencimento local está constantemente reiterada nos temas abordados, no olhar da equipe realizadora e nas experiências de sujeitos plurais representados nesses filmes. Esses filmes, de baixo-orçamento, diferem em perspectivas e escolhas formais dos mais famosos e dispendiosos lançamentos da década passada que se situam em periferias e tematizam sua violência, à exemplo de Cidade de Deus (Fernando Meirelles, 2002) e Tropa de Elite (José Padilha, 2007). Sob menor pressão de apoiadores e financiadores, a particularidade dos filmes de baixo-orçamento é que tendem a expressar com maior originalidade a imaginação dos autores e viabilizar mais recorrentemente olhares e temas considerados tabu (Sconce, 1995). Os sujeitos cujas vozes são enfatizadas no cinema de Queirós, cujas experiências jogam com a precariedade, são aqueles rotineiramente silenciados no processo modernizador brasileiro e brasiliense, ou tratados como coadjuvantes e perigosos em Tropa de Elite e nos tantos filmes e programas televisivos brasileiros policialescos situados em periferias. As temáticas da violência policial na periferia, das diferenças sociais brasileiras, nada novas no cinema realizado no país, são exploradas por Queirós através do ponto de vista do "Outro". Essa situação existencial que suas personagens corporificam articula a oposição binária centro/periferia a outras como brancos/negros, políticos/povo e candangos/burocratas. O presente capítulo divide-se, então, em uma série de tópicos que abordam os filmes de Queirós de forma separada e cronológica.

autores colocam que "as fronteiras entre documentário e ficção nunca são estanques e variam, consideravelmente, de uma época a outra" e também no espaço (Idem., p.86-7). Em afinidade, Bill Nichols (2010, p.47) defende que "a definição de documentário é sempre relativa ou comparativa", fundamentando-se em diferenciação à ficção. 
A representação da Ceilândia e dos ceilandenses no cinema de Adirley Queirós.

\subsection{Rap, o Canto da Ceilândia (2005)}

Este primeiro curta-metragem foi sumariamente apresentado na introdução. Em entrevista, Queirós (apud Cantuaria, Chacon e Guimarães, 2015, p.31) afirma ter elegido os 4 rappers que participam do documentário - Marquim da Tropa, X, Jamaika e Japão - a partir de dois critérios: o desemprego e o pertencimento à Ceilândia desde o seu primeiro ano, ou seja, estar na faixa etária dos 35 anos. Ainda que se trate de um recorte dentre a Ceilândia e dentre seus rappers, o filme constrói, através da forma documental, um "nós" local que se apresenta mais ou menos como unidade nos discursos e rimas dos entrevistados, produto da história da cidade e do quotidiano das ruas. Queirós comenta em entrevista posterior ao filme sobre a centralidade que a música ocupa neste curta-metragem: "Eu achava que o rap era de fato a música popular brasileira [...] Então, vendo hoje, eu acho o filme muito simples, até simplório na forma, mas era um filme que tinha um discurso muito claro para a gente" (Idem.). De maneira conforme, nos relatos dos rappers ao documentário, sua música tem "a responsabilidade de narrar a realidade". Logo, temos acesso ao anseio por narrar o que Avtar Brah (2006) definiria como diferença como relação social, que se refere aos aspectos estruturais e formas sistêmicas de significação que constroem e organizam os grupos na vida social a partir de categorias como raça, classe e origem.

A "realidade" vivenciada e narrada da Ceilândia se entremeia aos estigmas e estereótipos com os quais os MC's têm de lidar. Relatam que a cidade-satélite foi apelidada de "caldeirão do diabo", "planeta dos macacos", "fim do mundo", "terra sem lei", dentre outros nomes que a definiram em termos morais e racistas, simultaneamente entendida como precária e perigosa. Nas palavras de X "você ia pra baile, ia pra algum lugar, falava que era da Ceilândia, a mulherada não queria nem conversa, pensava, pô: ou foi, ou é ou será bandido". Esses estereótipos vinculados ao local estão intimamente ligadas à construção das identidades de grupo e sentimentos de comunidade: o mesmo rapper X é autor, com o grupo Câmbio Negro, de músicas que jogam com esses estigmas buscando sua ressignificação. Uma delas é apresentada como emblemáticas no rap ceilandense, onde canta: 
"Sou negão careca da Ceilândia mesmo, e daí?". Outra tem como refrão "sou de raça", positivando a negritude ${ }^{10}$. Assim, esses rappers, ao passo em que narram sobre o quotidiano da Ceilândia e caracterizam sua população, atribuem sentido simbólico às suas experiências, engendrando uma "luta sobre condições materiais e significado" (Brah, 2006, p.360). Seguindo a conceituação de Avtar Brah, a experiência não pode ser encarada como um reflexo transparente de uma realidade que o sujeito vivencia, mas está atrelada a um processo de significação dessa realidade. As experiências comuns de precariedade vivenciadas no passado figuram como um lugar de contestação das relações sociais: os entrevistados defendem reiteradamente a bandeira local, o orgulho de ser negro, a cultura rap atrelada ao popular.

Ao passo em que imperativos sociais agem sobre os sujeitos os segregando a partir de seu status, quando essas diferenças e formas de exclusão são experimentadas subjetivamente são traduzidas $^{11}$, e é nessa forma em que figuram no cinema de Queirós ${ }^{12}$. Ao passo que o filme expõe as diferenças que se estabelecem entre as cidades através de discursos, práticas quotidianas e relações institucionais e socioeconômicas, de maneira entrelaçada traz manifestos valores que transpassam os sujeitos entrevistados (acessíveis em suas músicas e depoimentos), índices dos mundos a que pertencem e através dos quais atribuem sentido ao que vivenciam, propiciando sua identificação como grupo. Suas demandas e experiências constroem, ainda que de maneira fragmentada, uma identidade local (fra-

10 Vemos $\mathrm{X}$ declamar o "privilégio de ser negro [...] uma raça que com o próprio sangue construiu o Brasil". No que toca à positivação simbólica da periferia, DJ Jamaika afirma em uma das entrevistas: "a gente que levantou a bandeira da nossa área mesmo, de levantar a bandeira Ceilândia e sacudir ela, e falar que a gente mora aqui e que aqui é bom".

11 A subjetividade, para Avtar Brah, trata-se da "modalidade em que a natureza precária e contraditória do sujeito-em-processo ganha significado ou é experimentada como identidade" (2006, p.372). Nesses termos, trata-se de uma releitura do social e das relações sociais, diferente deles mas relacional aos mesmos: media a relação do sujeito com o social. A subjetividade, "condição mesma para a constituição daquilo a que chamamos 'realidade"” (Idem., p.360), está atrelada à experiência individual e às identidades de grupo. Ao mesmo tempo, implica em uma série de instabilidades e projeções, de forma que "não é nem unificada nem fixada, mas fragmentada e constantemente em processo" (Idem., p.368). Há uma "miríade de maneiras imprevisíveis" com que a construção social dos sujeitos se configura em sua psique, invariavelmente "em relação ao repertório político dos discursos culturais à sua disposição" (Idem., p.362); sendo a subjetividade "o lugar do processo de dar sentido a nossas relações com o mundo". (Idem., p.371).

12 As formas de controle e segregação Distrito Federal já foram muito mais didaticamente explicadas há cinquenta anos em Brasília - contradições de uma cidade nova (Joaquim Pedro de Andrade, 1967), ou em textos científicos como os de Gouvêa (1998) e Holston (1993), ou mesmo nos filmes de Vladimir Carvalho. Nos interessa no cinema de Queirós a forma de experiência e agenciamento das diferenças sociais pelos ceilandenses. 
A representação da Ceilândia e dos ceilandenses no cinema de Adirley Queirós.

turada por raça, classe, gênero, dentre outros marcadores), discursivamente criada a partir das diferenças, mas também uma forma de interpretá-las e significá-las.

\subsection{Fora de campo (2009)}

Fora de campo (2009), segundo filme de Adirley Queirós, é um documentário média-metragem sobre um grupo de jogadores e ex-jogadores ceilandenses de futebol das séries $\mathrm{B}$ e $\mathrm{C}$ do campeonato brasileiro, carreira trilhada pelo próprio diretor, onde conheceu previamente os participantes do filme. No início, letreiros apontam que apenas $8 \%$ dos jogadores profissionais de futebol no Brasil fazem parte das séries A e B, a "elite" do esporte, enquanto o mais expressivo contingente desses profissionais sofre, sistematicamente, pagamentos atrasados, ausência de pagamentos, carteiras não-assinadas, etc. Estão sugeridas e explícitas na narrativa denúncias à pressão psicológica e condições precárias de vida que os pequenos clubes oferecem a esses profissionais, principalmente quando superam a faixa etária média da profissão e passam a ser esquecidos pelo mercado. É o caso dos entrevistados, todos com mais de 35 anos de idade.

A articulação entre sua classe e localização espacial relaciona-se a aspectos mais íntimos de cada um desses sujeitos na abordagem do filme, que compreende suas casas, famílias, aspirações, memórias de glória, reflexões, etc. Todos fora ou quase fora do mercado do futebol, os personagens são apresentados dentre a crueza do dia-a-dia. Um deles trabalha em um camelô, outro é segurança em uma estação de trem, outro é árbitro de jogos locais. Maninho, atuante como camisa 10 de um time da segunda divisão no Distrito Federal, é o único dentre os sujeitos documentados que ainda joga. Muito significativamente, em uma cena quando acompanhamos as comemorações da vitória do seu time na final de um campeonato, Maninho tira a medalha colocada em seu pescoço por um dos dirigentes do seu clube, enquanto o intima: "Me paga agora hein. Me paga o que me deve". De braços cruzados, o camisa 10 mantém-se afastado do espírito comemorativo dos colegas. Tal como em Rap, o canto da Ceilândia, o filme costura denúncia social à apresentação 
do universo particular dos entrevistados, o que pode ser uma marca de estilo facilitada pela proximidade entre o diretor, o universo documentado e os sujeitos do documentário.

\subsection{Dias de Greve (2012)}

Terceiro filme de Queirós, Dias de Greve é a sua primeira ficção. O curta-metragem dá seguimento a uma forma de fazer recorrente em ficções de baixo-orçamento, que remete ao neo-realismo italiano, lançando mão de elementos "documentais" - como as ruas como cenários e as suas iluminações espontâneas, os atores não -profissionais, ou outros elementos dispostos no quotidiano como as formas de vestir e falar, as paisagens urbanas, etc - na construção de uma moldura para a ficção. A narrativa se centra em um grupo de serralheiros na Ceilândia em desacordo com o patrão. Há uma greve na pequena empresa que, ao longo do filme, aumenta progressivamente o grau das tensões em jogo. Parte do drama situa-se em que alguns dos não-grevistas estão trabalhando na escola de samba, simultaneamente contrariando a greve e colaborando duplamente com o patrão, patrono da escola. Enfim, após uma série de conflitos entre os trabalhadores, após o acirramento da precarização econômica a que sujeitam a si e às suas famílias em razão da greve, têm de voltar ao trabalho mesmo sem o desejado aumento. Na cena final, tanto os serralheiros quanto o patrão comemoram o carnaval desfilando pela mesma escola de samba, embora em alas diferentes, reproduzindo suas diferenças de classe e status social.

Como podemos notar, Dias de Greve e Fora de Campo enfatizam as desigualdades socioeconômicas como articuladas dentro da periferia, dando evidência às fragmentações internas da cidade-satélite e à formação de grupos subalternos dentre os ceilandenses (podemos lembrar também dos rappers em Rap, o canto da Ceilândia, que reclamam da falta de trabalho e a desvalorização institucional do rap). De maneira entrelaçada, a localização dos filmes na Ceilândia propõe um olhar sobre como são vivenciadas as interesecções entre pertencimento de classe e pertencimento à periferia. 


\subsection{Nancy em A cidade é uma só? (2012)}

A cidade é uma só? (2012), primeiro longa-metragem e quarto filme do diretor, foi realizado a partir de recursos de um edital para documentários do Fundo de apoio à Cultura, da Secretaria da Cultura do Governo do Distrito Federal e TV Brasil, com a temática dos "50 anos de Brasília". Adirley Queirós tematizou a história de Brasília principalmente através da Ceilândia, e mesclou documentário (o exigido pelo edital) com ficção. Devido à extensão do filme e ao tema que aborda, é talvez sua produção mais didática no que toca às relações históricas entre as duas cidades.

No começo do filme vemos uma série de imagens de arquivo. Durante a década de 1950, a rápida construção da nova Capital Federal foi registrada em tom ufanista em cinejornais encomendados pelo Estado, como As primeiras imagens de Brasília (Jean Manzon, 1956). Nas palavras do sociólogo Marcelo Ridenti (2005, p.85), a época estaria marcada por uma estrutura de sentimento ${ }^{13}$ de brasilidade romântico-revolucionária, alimentada pelo fato de que Juscelino Kubitscheck chamou Oscar Niemeyer, filiado ao PCB, para o planejamento de Brasília. O plano arquitetônico idealizado nesse contexto almejava superar os problemas urbanísticos da então Capital Federal Rio de Janeiro como as formas de segregação urbana que lá separavam brancos e pretos, ricos e pobres $^{14}$. Em Brasília os funcionários de baixo escalão teriam os mesmos direitos à cidade que os mais altos funcionários. O discurso oficial, corroborado pelos documentários resgatados em A cidade é uma só? como material de arquivo, era de que a nova cidade seria "a maior realização do urba-

13 A estrutura de sentimento, conceito de Raymond Williams (1979), apresenta-se como uma resposta a determinadas mudanças na realidade social, "um fenômeno vasto, com diversas expressões artísticas e também políticas" (Ridenti, 2005, p.83), que permeia essa obras e formas de pensar sem que necessariamente os agentes percebam-na no momento em que a constituem. É a expressão do "pensamento tal como sentido e do sentimento tal como pensado" (Williams, 1979, p. 135 apud Ridenti, 2005, p.82), ou seja, liga-se às práticas sociais e aos hábitos mentais de uma época. A estrutura de sentimento da brasilidade romântico-revolucionária teria vigorado entre 1946 e 1964 , passando por JK e "especialmente no governo Goulart" (Ridenti, 2005, p.85).

14 Diversos episódios de limpeza social tomaram corpo na cidade do Rio de Janeiro após o fim da escravidão, passando, por exemplo, pela vacinação obrigatória no início do século XX, até mais recentemente com as desocupações no período das Olimpíadas Rio 2016. Não obstante, diversas outras razões para a construção de Brasília são levantadas em estudos, como "a necessidade de se ter uma capital, que, ao mesmo tempo que dificultasse uma ação militar externa, permitisse ao Estado um efetivo 'controle social' sobre a massa trabalhadora que, naquela ocasião, pressionava a administração do país com constantes greves e manifestações nas portas do Palácio do Catete." (Gouvêa, 1998, p.79-80). 
nismo no século XX" (Gouvêa, 1998, p.75), representando o "nacionalismo brasileiro", a modernização, e impelindo o país "para além das barreiras do subdesenvolvimento" (Holston, 1993, p.24).

A construção da nova capital, avançando para a região pouco explorada do centro-oestel, foi marcada por uma chamada oficial por mão de obra e "um processo de intensa migração" (Gouvêa, 1998, p.81). Ironicamente, com a finalização do projeto urbano o contingente de trabalhadores braçais não recebeu lotes de terra, passando a ocupar "invasões": barracos feitos de materiais precários em chão batido, que "deformavam" o desenho urbano idealizado ${ }^{15}$. Esse processo é resgatado no filme através de filmagens tomadas em 1972, conforme viemos a perceber na narração de um dos arquivos:

O vertiginoso crescimento das populações do Distrito Federal [...] provocou a quebra de padrões de habitabilidade nas chamadas invasões, onde não existiam as menores condições de higiene e conforto. A solução encontrada pelos administradores foi a mudança maciça daquele povo para onde se pudesse harmonizar os serviços públicos e dar condições melhores de vida àquela gente até então favelada. Coube também à Novacap participar da remoção dos moradores da antiga vila do IAPI para a cidade-satélite de Ceilândia, um local anteriormente deserto e que, naquela época, estava sendo preparado para receber esses novos moradores.

Desde o título do seu filme, Queirós questiona o otimismo e as promessas da Novacap e da Campanha de Erradicação das Invasões. A pergunta "a cidade é uma só?" coloca um ponto de interrogação no jingle que embalou a campanha ${ }^{16}$. A música, entoada por um coral infantil e construída para sensibilizar os moradores a aceitar a remoção com expectativas de um futuro melhor, era tocada na televisão e em carros de som nas vilas a serem erradicadas. A escolha de Queirós por transformar a afirmação em uma pergunta sugere a possibilidade de sua negação: a cidade não é uma só, mas segregada, desigual.

$15 \mathrm{Na}$ interpretação de James Holston (1993, p.200), os planejadores de Brasília, ao exorcizar aqueles que deformaram seus planos (os favelizados, dentre outros), "criaram uma versão exagerada - quase uma caricatura - daquilo de que procuravam escapar [...] fizeram de Brasília um exemplo de estratificação espacial e social".

16 "Vamos sair da invasão / A cidade é uma só! / Você que tem / um bom lugar pra morar / nos dê a mão, ajude a construir nosso lar / Para que possamos dizer juntos: / A cidade é uma só!". 
Uma das principais personagens do filme é Nancy, uma das crianças escaladas nas escolas da periferia para cantar o jingle que erradicaria sua família. No filme, já uma adulta madura que acompanhou a remoção e posteriormente a urbanização da Ceilândia, rememora a Campanha e visita arquivos oficiais relacionados ao acontecido, buscando por uma foto sua, que não consegue encontrar. A personagem aparece em certo momento do filme em uma rádio em Águas Claras, periferia do Distrito Federal, cantando a música Postal do Plano de Rai Melodia, o que faz acompanhada de um violonista. De inspiração sertaneja na sonoridade, a canção expressa em sua letra: "Eu tinha plano de morar no Plano, de estudar no Plano. Era meu plano trabalhar no Plano [...]. Passados anos, tantas lutas, tantos planos, jogaram meus planos na periferia". Sua trajetória individual encontra coro na do compositor e, como a narrativa do filme nos faz crer, na de um expressivo contingente de moradores da periferia brasiliense. Segundo o arquiteto Luiz Alberto Gouvêa, a exclusão territorial no Distrito Federal atingiu negativamente as condições socioeconômicas do contingente tornado periférico (1998, p.83) e reestruturou forçadamente seus modos de vida ao refazer a organização urbana de suas vilas:

a mudança das famílias causou uma significativa redução de suas rendas, devido à distância do novo núcleo em relação ao centro de empregos (na época, o Plano-Piloto) e principalmente em face do custo do transporte, que praticamente impediu a participação dos filhos menores e da mulher na composição da renda familiar, ficando esta basicamente apoiada nos parcos ganhos do chefe da família, percebidos, geralmente, como operário da construção civil. As mulheres, em sua grande maioria, ficaram impedidas de desenvolver suas atividades, como, por exemplo, as lavadeiras (uma das profissões mais praticadas pelas pessoas da antiga Vila), que se viriam impossibilitadas de trabalhar, pois a Ceilândia, nos primeiros tempos, não dispunha de água.

Sobre suas memórias da remoção, Nancy, em certo momento, conta: 
[...] O discurso deles era que iam tirar de lá para uma situação legalizada, com lote, com toda a infraestrutura, e na verdade não foi isso, né? Quando a gente chegou aqui não tinha nada disso também. $\mathrm{O}$ que eles queriam na verdade era achar um lugar pra jogar aquele monte de pobre, né. Tirar a coisa feia que era lá próximo de Brasília mesmo e trazer pra um lugar o mais distante possível. E quando nós chegamos aqui foi um outro choque, né: que era muito mato, muita terra, muita poeira e "infra" nenhuma.

Segundo o que oferece o filme, ao contrário de ser um eixo de desenvolvimento e progresso que suavizaria as diferenças entre classes, Brasília expele um contingente populacional, maquiando o subdesenvolvimento a ser combatido, fomentando a continuidade da desigualdade do povo brasileiro e indo de encontro à narrativa teleológica do progresso que seduziu os trabalhadores braçais migrantes na década de 1950. Nesses termos e nesse contexto, a perspectiva predominante no cinema proposto por Queirós acompanha um dos fundamentos da perspectiva teórica pós-colonial, que é a formulação de uma densa "crítica do modernismo enquanto teleologia da história" (Costa, 2006, p.85). Os pressupostos oficiais da fundação de Brasília, correlatos ao modernismo e à modernização, resgatados através dos arquivos na introdução do longa-metragem, são postos em xeque ao longo da narrativa pelos depoimentos $\mathrm{Nancy}^{17}$, que ressalta o caráter violento da remoção vivenciada pelos ceilandenses:

[...] Tava você no seu barraco tranquilamente e daqui a pouco chegava uma equipe, fazia um $\mathrm{X}$ no seu barraco. E não tinha muita explicação, né? [...] E esse X era pra indicar que esse barraco já estava de fato legalizado dentro da vila do IAPI pra ser transferido pra Ceilândia [...] ou era pra Ceilândia ou cada um se virava pra ir pra outro lugar. Não tinha a opção de ficar lá [...] Eles queriam o terreno né, eles queriam aquele espaço.

17 Outro depoimento da personagem, significativo para que compreendamos a toada do filme e o processo de remoção: "O lugar que a gente morava era rota de voos nacionais e internacionais. Essa foi uma das grandes preocupação de tirar a invasão de lá. Porque as autoridades passavam e via aquela coisa feia, né. Um monte de pobre amontoado. Então ele, o governador, resolveu criar a Campanha de Erradicação de Invasões. Isso já em 69, né? E dali foi muito rápido. A remoção das pessoas de lá foi muito rápida. Na década de 70 organizou tudo e em 71 a gente já tava chegando em Ceilândia. [...] Não era retirar, era expulsar. Porque não tinha uma conversa prévia, não tinha uma reunião pra explicar, não tinha nada disso". 
A representação da Ceilândia e dos ceilandenses no cinema de Adirley Queirós.

\subsection{Dildu e Zé do Bigode em A cidade é uma só? (2012)}

No mesmo filme, após uma das locução de arquivo encomendadas pelo governo que fala dos "longos caminhos da nova civilização brasileira. Brasília, ao irradiar-se para o norte, para o centro e para o sul", através da "construção de estradas vitais [...] uma épica aventura", vemos Dildu, personagem morador da Ceilândia que trabalha de faxineiro em Brasília, enquanto dorme no ônibus à noite voltando para casa após o expediente, nos 50 minutos do estrada entre Ceilândia e Brasília. A cena propõe ao público uma leitura irônica da narração apresentada. Dildu, personagem ficcional vivenciado por Dilmar Durães, se divide entre seu trabalho regular e concorrer na campanha para vereador distrital. Seu partido, fictício, é o PCN, Partido da Correria Nacional. Mesmo quando atuando como candidato, sua fala é permeada de gírias, ritmada e entonada de forma tipicamente local, o que contrasta da fala asséptica dos diversos narradores de filmes institucionais apresentados. Dentre as suas propostas de campanha, declaradas enquanto distribui panfletos na rua, ouvimos:

Chega de hereditariedade para servidor do Estado, escolas das cidades-satélite com cursos de formação para servidor público. [...] Nós vamos botar a favela pra aprender e virar classe média cabulosa também [...] nós vamos fazer cinema de um real, filme de amor, filme de aventura e caratê [...] vamos obrigar os hospitais a receber o pessoal do entorno sem precisar apresentar foto e endereço [...] vamos quebrar com essa mania de hereditariedade, tem gente aí que tem o bisavô, o tataravô, que é servidor público desde 1500. Nós temos que dar a oportunidade também já que a porra do Estado é nosso, então por quê que a gente não tem condições?

Dildu afirma ser e buscar representar politicamente o "caboclo comum". Seu orçamento de campanha é modesto. Seus trajes são populares. Seu único assessor é seu cunhado. Seu problemático veículo de lida é o seu carro particular, um antigo Volkswagen Santana. O seu jingle como candidato, bastante distinto daquele da Campanha da Erradicação das Invasões entoado por angelicais timbres infantis, tem como fundo um rap em cuja base instrumental ouve-se o som 
de diversos tiros que dão o ritmo da música, contraste que explicita as diferenças de linguagem entre o aspirante a político periférico e os burocratas brasilienses. Marquim da Tropa, rapper cadeirante já apresentado em Rap, o canto da Ceilândia, aparece agora como o produtor fonográfico desse jingle em seu estúdio caseiro, onde busca em conjunto com Dildu por uma sonoridade que definem como "política e gangster".

Zé Antônio ou Zé Bigode, apresentado como cunhado de Dil$\mathrm{du}$, exerce o papel de motorista e cabo eleitoral para o parente. Fora isso, vende terrenos na Ceilândia, tomando parte na redistribuição de lotes, ao passo em que afirma se chocar com a ocupação irregular da área. Mesmo a Ceilândia sendo uma cidade planejada, "formou becos e espaços exageradamente amplos e áridos" (Saboia e Sandoval, 2012, p.7), o que fez com que a cidade tenha sido "acrescida de loteamentos clandestinos e apropriações indevidas do espaço público" (Ibidem.), em "um traçado urbano bem diverso do arranjo espacial dos assentamentos erradicados" (Gouvêa, 1998, p.84). Se através de Nancy e dos elementos de arquivo anteriormente mencionados a narrativa faz um elo com a história oficial da Ceilândia, Zé Antônio e Dildu se debatem mais enfaticamente com problemas contemporâneos e públicos na cidade. Em sua campanha, o candidato a deputado distrital afirma buscar a ressignificação de "tudo o que já rolou de ruim no passado". Para tanto, adota um "X" como símbolo de sua candidatura, remetendo à marca de spray feita na porta dos barracos que deveriam ser desocupados na remoção da Vila do IAPI e simultaneamente a um deslocamento de significado atribuído à essa marca, de maneira que agência e autoficcionalização possibilitados pela trajetória fantástica de Dildu apresentam uma possibilidade de releitura histórica em articulação com o quotidiano.

Na conclusão do filme e das campanhas eleitorais, Dildu encontra-se a pé e só no vasto e ensolarado planalto brasiliense, cansado e fustigado pelo Sol. Tatiana de Lima (2016, p.16) já evidenciou que, conforme se aproxima o fim do filme, Dildu é mostrado "cada vez mais isolado, perambulando sozinho e deixando panfletos dentro de caixas de correio em ruas vazias". Nesse momento do clímax da narrativa, em que caminha desanimado, passa ao seu lado uma enorme carreata petista, 
cheia de carros, balões e pessoas, com um potente equipamento de som anunciando candidatos concorrentes. Tínhamos visto, em uma cena anterior, o modesto equipamento de som de Dildu consumir a bateria do seu carro, embaraçando sua campanha de rua. Essa comparação sugerida pela montagem aponta para o silenciamento da periferia frente às propostas políticas hegemônicas. O PT, que dentre os partidos de maior expressividade à época era considerado comumente como representante de um olhar mais voltado ao "social", representa no proposto pelo filme a força centralizadora daquilo que já é habitual em Brasília. A corpulência da campanha governista impõe-se sobre a voz do cansado e desequipado concorrente da Ceilândia, de forma que o desfecho que vemos "satiriza a efetividade da disputa por voz dos periféricos via representação nos mecanismos da política institucional" (Oliveira e Maciel, 2017, p.23) e marca a impossibilidade da "ressignificação" como imaginada pelo personagem. Dildu volta ao seu cotidiano na área da limpeza em uma faculdade do Distrito Federal, onde transita despercebido.

\subsection{Marquim da Tropa e Sartana em Branco sai, preto fica (2014)}

O MC da Ceilândia Marquim da Tropa, personagem/sujeito recorrente nos filmes de Queirós, perdeu a mobilidade das pernas em função de uma bala perdida projetada pela polícia durante uma invasão no baile black do Quarentão, na Ceilândia, em 5 de março de 1986, quando teve sua coluna irreversivelmente atingida. O episódio é narrado por ele na primeira cena de Branco sai, preto fica, em um presente especulado onde é locutor em uma rádio pirata no porão de sua casa. Marquim da Tropa assina a trilha sonora do filme com o mesmo nome do seu personagem, favorecendo a diluição das fronteiras entre ficção e documentário. Sua trajetória pessoal e a deficiência adquirida no passado, rememoradas no início do filme, se mesclam a um enredo ficcional. Na sua rádio, revive constantemente a juventude perdida através das suas locuções, dos seus vinis com as músicas que dançava na década de 1980 com o seu grupo de break dance, quando "passava a semana dançando o passinho pra pegar as mina". "Aonde andará Sartana?", pergunta emocionado o locutor, 
esperando ser ouvido pelo amigo que, na mesma noite de 1986, foi atropelado pela cavalaria da polícia enquanto tentava fugir da confusão no baile do Quarentão, perdendo uma parte da perna direita.

Sartana é vivenciado pelo morador local conhecido fora do filme como Dj Shokito. Seu nome fictício no interior da narrativa remete a um pistoleiro de uma antiga série de filmes de faroeste. Como Marquim da Tropa, mescla sua trajetória pessoal com a construção de um personagem: um mecânico autodidata de próteses como a que usa em uma das pernas, as quais cataloga e conserta no seu galpão. Em certo trecho, relata sobre o processo de adaptação após episódio de violência sofrida na década de 1980:

O fim do Quarentão foi [...] meio que o fim de uma fase da minha vida. O fim de uma das minhas vidas. Eu comecei uma outra vida, né. Então aí foi um outro choque, quando eu saí do hospital e tal. Eu tive esse choque meio que com a realidade, um choque com as ruas, onde a gente dançava. Tudo que eu passava lembrava uma coisa: a escola, a gente ficava muito na esquina da escola, sentado numa anilha. Ali que a gente conversava, bolava ali os passinhos que a gente tinha, o quê que a gente ia fazer, encontrava os amigos e tal, ou quando a gente ia jogar bola. [...] a cidade toda era parte da minha vida. Parecia que cortou aquilo ali tudo de mim. Era uma parte que eu tava perdendo. Eu não tinha mais direito de tá naquela esquina e tal. Então cheguei em casa e não queria mais sair de casa.

A solidão declarada pelo personagem reitera-se quando folheia seu álbum de casamento sozinho em sua cama de solteiro, ouvindo a rádio de Marquim da Tropa que botou para tocar "um som de [dor de] cotovelo, mesmo". A ausência da esposa, que nem chegamos a conhecer, reitera a falta da presença feminina no filme e o forte diálogo com o passado que a narrativa estabelece. Os personagens são apresentados geralmente apartados, em seus mundos particulares. Marquim trabalha intensamente na rádio no porão de casa, retiro reiterado pela complicações em suas pernas: "eu nunca puxei cadeia, mas hora de hospital... já puxei muita hora de hospital", comenta.

A sensação de limitação e isolamento, ostensivamente presente no quotidiano dos personagens, extravasa a circunstância de seus 
corpos e imbrica-se à história de segregação da Ceilândia e à ordem policial título do filme, que deixa clara a espontaneidade do racismo e da discriminação institucional. "Branco sai, preto fica", o título do filme, é a ordem que os policiais gritavam no momento da invasão do baile black do Quarentão, conforme relata Marquim da Tropa. Os brancos têm o direito de sair da festa. Os pretos são escrutinados ou marcados violentamente. Pesquisas como as de Jacqueline Sinhoretto (et al., 2014) têm demonstrado a predileção estatal no Brasil e também especificamente no Distrito Federal pela vigilância e punição de corporalidades demarcadamente negras, periféricas e, na particularidade do caso policial, jovens e masculinas, escopo no qual se enquadram os dois personagens quando vitimados. $\mathrm{O}$ artigo $A$ filtragem racial na seleção policial de suspeitos (Idem., p.137) expõe como a abordagem da polícia envolve de maneira ostensiva a criminalização "da vestimenta, da música, da cultura, [...] também uma criminalização das formas de manifestação política e cultural", de forma que os pobres, negros, trajados ao estilo "hip-hop" ou "funk" (Idem, p.135), constituem-se como principais alvos dessas ações, "bem como dos efeitos negativos dela, como o abuso policial” (Idem, p.137).

A mestiçagem, como aponta a antropóloga colombiana Mara Viveros Vigoya (2013, p.80), seria a possibilidade dos não-brancos de se adequar à imagem do progresso e modernidade almejados na América-Latina, imagem que estabelece hegemonicamente a branquitude como "vir a ser". O acesso do mestiço ao status de branco honorário, nessa lógica, passa também pela "adoção e a imitação das boas maneiras, [d]os hábitos, gostos e comportamentos que distinguem os europeus da plebe de negros, índios e mestiços sem educação". Conforme o filme, primeiro de Queirós que aborda frontal e enfaticamente a violência policial na Ceilândia - cidade historicamente ligada às populações não-brancas do Distrito Federal -, aqueles que negaram o embranquecimento - Sartana e Marquim, ex-b-boys da cultura black -, ao afirmarem sua negritude e sublinharem as suas diferenças com o hegemônico (no caso, a branquitude), têm suas próprias condições de interação com o mesmo amputadas. Esses jovens negros, "outros" à forma idealizada da masculinidade moderna-ocidental, são aqueles que, segundo Vigoya (Idem., p.75- 
6), "adquirem de imediato um status de incivilidade e começaram a ser percebidos como uma ameaça interna da nova ordem social moderna", terminando, conforme propõe o filme, disciplinados e literalmente marcados pela polícia.

Marquim da Tropa e Sartana, ao passo em que representavam em sua juventude na década de 1980 o "suspeito-padrão" - jovens negros, pobres e periféricos, afeitos ao hip-hop -, no presente enunciativo da narrativa representam o grupo específico daqueles com deficiência adquirida em decorrência da violência estatal. Por habitarem entre os 30 e 64 anos de idade, povoam, segundo dados da Codeplan $\left(2013\right.$, p.17) ${ }^{18}$, a faixa etária com maior número de deficientes motores no Distrito Federal. Na visão do diretor, conforme entrevista,

Ceilândia é um dos lugares que mais tem pessoas em cadeira de rodas aos 40 anos. Nos anos 80 , atingidas por balas da polícia. É assustador você andar pela cidade e ver o tanto de cadeirantes andando para cima e para baixo, de jovens adultos, vamos dizer assim.

As dificuldades de deslocamento dentro do Plano Piloto, já bastante salientes para pedestres devido à distância entre os diferentes pontos da cidade e à quase abolição as ruas e esquinas ${ }^{19}$, potencializa-se ainda mais no que toca aos deficientes físicos ${ }^{20}$. Segundo a Coordenação de Planejamento (CODEPLAN, 2013, p.28) a capital necessita de "adaptações que objetivem o amplo acesso aos monumentos e prédios públicos", ao passo que Brasília "ter se tornado em patrimônio da humanidade provoca morosidade na execução de qualquer projeto de adaptação ou reforma para permitir a acessibili-

18 Os dados baseiam-se em senso do IBGE de 2010.

19 Para compreender esse aspecto, evoco a locução do filme Brasilia: planejamento urbano (Fernando Campos, 1964), onde explica-se que em Brasília: "[...] houve o propósito de aplicar os princípios da técnica rodoviária, inclusive a eliminação dos cruzamentos, à técnica urbanística. Assim, foram dadas ao motorista da cidade todas as vantagens do motorista de estrada: tráfego desimpedido e contínuo".

20 Segundo matéria do Correio Braziliense, publicada em 22/8/16 e da autoria de Flávia Maia e Nathália Cardim, "Embora seja capital do país e tenha a mais alta renda per capita, o Distrito Federal não tem requisitos mínimos de acessibilidade em $93,52 \%$ das 5 mil paradas de ônibus existentes. Essa falta de acesso respeitoso aos deficientes físicos foi tema de uma auditoria do Tribunal de Contas do Distrito Federal (TCDF) [...] O relatório mostrou ainda que 99,07\% das calçadas têm falhas, o que dificulta a locomoção dos deficientes físicos, assim como $90,74 \%$ dos pontos não dispõe de piso tátil e $61,22 \%$ não têm rampa próxima para a travessia da via". O texto, intitulado, "Deficientes físicos encontram dificuldades para se locomover de ônibus no DF", é acessível em: < https://bit. ly/2F $6 \mathrm{Mmbl}>$, acesso em 13/7/19. 
dade em áreas e monumentos tombados" (Idem., p.27-8). Em um levantamento sobre calçadas do Brasil publicado pelo portal voltado à mobilidade urbana Mobilize Brasil (2013), Brasília foi avaliada com nota 4 de 10, sendo 8 a média aceitável conforme os critérios do estudo. Essas dificuldades, que sublinham a incompatibilidade desses dois personagens com a capital, são provavelmente mais salientes na periferia, onde o espaço público tende a carecer ainda mais de investimento.

\subsection{Dimas Cravalanças em Branco sai, preto fica}

Dimas Cravalanças - Dilmar Durães -, um viajante do tempo que adentra o universo diegético ${ }^{21}$ através de um dispositivo de ficção-científica, é um terceiro personagem bastante importante nesse filme. $\mathrm{O}$ vemos, no começo do longa-metragem, chegar à Ceilândia em uma máquina do tempo/nave. Seu dispositivo, um contêiner despido de conforto, balança bruscamente enquanto Cravalanças segura-se em um canto. Após a turbulência, o vemos sentado no chão com um caderno amassado em mãos, produzindo um relatório de chegada em um rádio comunicador. Descobrimos então que trata-se de um agente federal terceirizado enviado do futuro à procura de Sartana, quem teria as provas que necessita sobre a violência policial e estatal contra populações negras e marginalizadas. A missão de Cravalanças consiste em obter e enviar esses dados à década de 2070, onde/quando servirão de base para mover uma ação contra o Estado brasileiro. Ao longo do filme, esse agente cujo sobrenome é bastante simbólico no sentido da intenção de reparação social, recolhe uma série de arquivos, fotografias, e o vemos ouvindo a rádio de Marquim da Tropa, onde acessa as trágicas memórias do baile do Quarentão.

Logo após a turbulenta chegada, demonstra-se inquieto na nave mal iluminada, procurando com uma lanterna, em meio a ruídos suspeitos de pane elétrica, a fonte desse mal funcionamento. Sua nave ser um container praticamente vazio é duplamente significativo: em parte, 21 Diegese, palavra, de origem grega, se refere àquilo "que se passa conforme a ficção que o filme apresenta, tudo o que essa ficção implicaria se fosse supostamente verdadeira" (Aumont e Marie, 2003, p.77). Em afinidade, de acordo com Vanoye e Goliot-Leté (2002, p.40) o termo, "próximo, mas não sinônimo de história (pois de um alcance mais amplo), designa a história e seus circuitos, a história e o universo fictício que pressupõe (ou 'pós-supõe'), em todo o caso, que lhe é associado". 
demonstra uma solução estética criativa frente ao baixo-orçamento do filme; ao mesmo tempo, refere-se a uma forma de agenciamento associada à precariedade de recursos, construindo o personagem à semelhança dos órgãos que trabalham com direitos humanos ou serviços voltados a populações marginalizadas ou carentes (Sinhoretto et alli., 2014, p.142). Isso se reitera no figurino constantemente informal do personagem, no seu bloco de notas amassado, na sua quase ausência de equipamentos, na sua aparente e declarada ansiedade ${ }^{22}$, nos problemas técnicos de comunicação com os quais têm que lidar para comunicar-se com o tempo de onde veio, na satírica defasagem do seu inventário. De maneira correlata, a existência da missão de Cravalanças aponta por si para que a falta de uma reparação estatal para os ceilandenses e para os casos de abusos da violência policial seria postergada para pelo menos até a década de 2070, quando apenas então o agente entra em ação. Ironicamente, após coletar as provas, como viemos a descobrir em um momento mais avançado do filme por meio de uma mensagem de sua correspondente do futuro, a Vanguarda Cristã chega inesperadamente ao poder e, por isso, Dimas Cravalanças tem sua missão cancelada e corre o risco de não mais conseguir retornar ao tempo de onde partiu.

\section{8}

Após um breve olhar sobre estes filmes de Queirós em suas formas de representação de sujeitos e grupos da Ceilândia e suas formas de vivenciar, subjetivar e agenciar as diferenças, constatamos como os processos de identificação e diferenciação ressaltados pelas narrativas são transpassados por uma diversidade de demarcações simbólicas. Ao passo que sublinha-se eventualmente uma diferença dicotômica e hierárquica entre Ceilândia e Brasília, também constroem-se hierarquizações que operam dentre a própria periferia, formando os grupos subalternos a quem Queirós dá voz; os quais emergem a partir de diferenças como a racial, a de capacitismo, a 22 Ouvimos, logo na sua primeira fala: "Relatório de chegada: data ainda desconhecida. Material perdido na viagem: identidade, dinheiro, cartão de crédito e alguns equipamentos. Tô fudido. Repito: Fudido! Licitação da nave é ruim, uma praga, uma bosta! Contenção de gastos?: enfiou a sobra onde? Sequelas da viagem: transtornos psicológicos, cabeça, náuseas, contração e vômito. Tô lombrado! Circuit. Língua bamba! Dificulta contato". 
econômica, a idade, o gênero, etc, embora que, no que toque à diferença socioespacial, recorra a tematização prioritária da Ceilândia e a perspectiva de seus moradores.

Posta a caracterização dos canadenses e a relação entre Brasília e Ceilândia como representada até então nessa cinematografia e também no artigo, em um último tópico nos deteremos de forma aprofundada nos últimos filmes do diretor, desde A cidade é uma só? até mais enfaticamente Branco sai, Preto Fica (2014) e Era uma vez Brasília (2017), ambos os quais lançam mão de um estilo que poderíamos caracterizar como ficção-científica ou realismo fantástico na construção de uma Ceilândia distópica. De maneira correlata à análise do teor ficcional desses filmes, abordaremos os agenciamentos dos personagens nesses cenários, considerando que a ênfase na ficção no interior dessas narrativas redimensiona as experiências e possibilidades de ação dos personagens e enfatiza a forma com que os sujeitos que os interpretam subjetivam e experimentam as diferenças e forças que se põe em jogo no universo diegético e no mundo social.

\section{A CEILÂNDIA ESPECULADA}

Os últimos três filmes de Adirley Queirós - respectivamente A cidade é uma só? (2012), Branco sai, Preto Fica (2014) e Era uma vez Brasília (2017) -, diferente dos primeiros, tratam-se de longasmetragens que mesclam recursos ficcionais com documentais, onde os sujeitos/atores colaboram criativamente com o diretor projetando ficções existenciais. As fronteiras entre documentário e ficção, que nunca foram estanques ou universais, são provocadas ou mesmo ativamente borradas por esses filmes. Assim, ainda que os filmes partam de argumentos e pesquisas prévios, foram empreendido sem roteiro oficial (Isaias, 2017, p.31; Suppia, 2015, p.25; Queirós apud Dalpizzolo, 2012), como uma criação conjunta com os demais envolvidos, conturbando a forma de fazer ficcional com a documental. Se em Rap, o Canto da Ceilândia o local é abordado com uma expectativa de apreensão do "real", seus três últimos filmes apostam em encenações a partir do realismo já apreendido desde o começo de sua filmografia, impregnando as imagens de forma mais complexa à subjetividade dos 
sujeitos representados. O jogo em que esses sujeitos se situam - entre a representação de si e a construção de personagens complexos como Dildu, Dimas Cravalanças e Sartana - afasta esses filmes da expectativa quixotesca de retrato da realidade, ao passo que viabiliza materialmente - através dos corpos e espaços pré-dispostos - a própria existência da ficção em uma lógica de baixo-orçamento.

$\mathrm{O}$ quotidiano dos ceilandenses se mescla densamente, em Branco Sai, preto Fica e Era uma vez Brasília, à ficcionalizações do próprio espaço, que, através de hipérboles fantásticas, sublinha a segregação, o racismo e o conflito/diferença entre Ceilândia e Brasília. Assim, o cinema de Queirós migra para um estilo híbrido entre documentário e ficção ao mesmo tempo em que passa a construir uma Ceilândia distópica. Podemos especular que $A$ cidade é uma só? inaugura nessa produção a construção desse tipo de universo diegético, justamente na conclusão pessimista que toma corpo no entorno de Dildu, personagem encarnada por Dilmar Durães, que, em sua campanha para tornar-se representante político da Ceilândia, é freado pelo poder centralizador dos políticos de Brasília.

Nesses longas-metragens recorre a visualidade das paredes rústicas da Ceilândia, retas e por vezes simultaneamente irregulares, em prédios dispersamente colocados. Os cenários urbanos parecem desorganizados, caóticos, são fotografados por vezes desidratados e sombrios (predomínio de cenas noturnas nos dois últimos filmes). As imagens ressaltam a destruição dos espaços, o caráter de abjeção ligado à periferia e a quem a habita, estendendo a desfiguração dessa geografia e desses objetos aos corpos dos personagens. Em entrevista, o diretor cita os filmes pós-apocalípticos Blade Runner (Ridley Scott, 1982) e Mad Max (George Miller, 1979) como referências visuais (Queirós apud Suppia e Gomes, 2015, p.407). Com o último certamente fraterniza nos cenários de aridez terrosa, nos muros empoeirados, nas imagens constantes de terra e ferro, nas ruas de chão batido, na apresentação ostensiva de grades e divisões físicas que, delimitando com objetividade o interior e o exterior, sugerem silenciosamente a presença da violência. Apontou a pesquisadora Ivonete Pinto (2015, s/p) que "Adirley Queirós é herdeiro do cinema marginal (ou udigrudi, ou de invenção), onde a liberdade estética (a 'feiura') e narrativa (a esculhambação) eram valores", estratégia 
que imbrica "o que quer contar e a maneira como quer contar". Cláudia Mesquita (2015, p.11) propôs em sua análise que em Branco Sai, preto Fica a Ceilândia é envolta em uma atmosfera de perda, cujo presente aparece "esfriado, melancolizado, distanciado, por vezes esvaziado e arruinado". Podemos certamente estender sua interpretação para Era uma vez Brasília, filme lançado depois do artigo da pesquisadora. Salientados esses aspectos, podemos passar a uma análise mais pormenorizada desses dois últimos filmes.

\subsection{Branco sai, Preto Fica (2014)}

Se em Branco Sai, Preto Fica os personagens raramente se encontram em Brasília, a presença da capital é constantemente reiterada através de dispositivos de controle que monitoram a Ceilândia, à exemplo de um toque de recolher e uma ronda noturna instaurados sobre a cidade-satelite. Uma locução solicita, ao cair da noite, "a todos imediatamente que tirem as crianças das ruas e retornem aos seus lares" com os documentos à mão. Assistimos, em uma das poucas aproximações de um personagem e da câmera com Brasília, Marquim da Tropa dirigindo só, pela estrada, seu carro adaptado para a condição de cadeirante. Uma trilha subitamente interrompe a música em seu rádio, avisando em robótico timbre feminino:

Se você está ouvindo esta faixa é porque está sob a área de controle da cidade de Brasília. Por gentileza, tenha em mãos o seu passaporte de acesso. Uma autoridade da polícia do bem-estar social irá abordá-lo no próximo guichê. Caso não possua o passaporte, evite constrangimentos e retorne ao seu núcleo habitacional.

Esse aparato eletrônico e burocrático, que monitora os veículos dos moradores do entorno brasiliense e que rege por seus sonos, liga-se à atuação mais ampla no universo diegético da "polícia do bem-estar social", que personaliza o controle de Brasília - "um governo alerta", como se auto-declara no filme - sobre a periferia. A presença dessa polícia é também sempre ausente, mediada por vozes sem corpos, atuando em um fora-de-campo que cerca os per- 
sonagens. Os passaportes dos quais os periféricos necessitam para chegar à Capital são apresentados em suas conversas quotidianas como difíceis de conseguir. Em certo momento vemos o passaporte de Marquim, onde lemos em letras garrafais "PRETO”, explicitando a racialização institucional. Esses dispositivos ironizam o fato histórico de que a população do entorno, das muitas vezes chamadas "cidades-dormitório", depende muitas vezes do plano-piloto para o trabalho ${ }^{23}$, ao passo que a distância os coloca em desvantagem no que se refere a encontrar e manter um emprego.

Nesse cenário adverso, os personagens também lançam mão de dispositivos: em um momento bastante representativo de uma relação subversiva e ativa com as tecnologias, Sartana crackeia e atualiza o software da prótese de sua perna, ou seja, quebra a criptografia imbricada pelo Estado no aparato usando-se de uma espécie de laboratório digital clandestino. Como bem notaram Oliveira e Maciel (2017, p.18-9) "o mesmo sitiamento que restringe a circulação dos moradores dos núcleos habitacionais ao plano piloto acaba por criar um nicho de mercado paralelo", fomentado pelo esquecimento vivenciado pelos personagens, que inclui a falsificação de passaportes para acessar Brasília, roubo da luz elétrica da estação de trem de Brasília, e outros agenciamentos que dialogam com a ilegalidade. No mesmo filme, Marquim da Tropa mantém clandestinamente em seu porão uma rádio pirata onde grava artistas locais para o que, viemos a descobrir, se consolidará em uma potente bomba sonora destinada a explodir Brasília ${ }^{24}$. Essa explosão, a ação mais radical no filme, é

23 Segundo o antropólogo James Holston "[...] a separação entre trabalho e residência (aliada à concentração daquele e à dispersão desta) contribui de forma significativa para o desenvolvimento de um padrão centrífugo de segmentação de classe, distribuindo-se conforme faixas de maior ou menor distância de locomoção entre o trabalho e o dormitório" (1993, p.167) e faz com que, nos momentos de lazer, os periféricos não vão a Brasília.

24 Sobre os sons e artistas que compõem essa bomba: primeiro, em um centro popular de comércio de eletrônicos na Ceilândia, Marquim e DJ Jamaika gravam som ambiente - Marquim na frente, com o fone, guiando Jamaika, atrás, com um microfone direcional -, em uma das raras excursões dos personagens a um espaço diurno ocupado por uma coletividade de pessoas. Com esse material buscam dar à bomba "a cara da Ceilândia", como comenta Jamaika. Em um segundo momento, gravam na rádio de Marquim um rap do ceilandense Dino Black, que expõe em sua letra a invisibilidade que vivencia no dia-a-dia como morador pobre da periferia do Distrito Federal. A última parte que vemos dessa captação são animadas músicas de forró interpretadas pela Família Show, remetendo à origem geográfica e às matrizes culturais do contingente de "candangos" que historicamente habita a Ceilândia. As letras dos forrós, satíricas e sensuais, positivam essa população: uma das músicas elogia uma mulher local "bonita e cheirosa", afirma que "aqui só tem mulher bonita/homem bonito"; enquanto outra, a "Dança do jumento", é performada pelo próprio cantor, que, em uma analogia fálica, rima/dança "balançando o instrumento". 
coordenada justamente pelos deficientes físicos, Sartana e Marquim da Tropa. Hirano (2015, p.225) já apontou que esses protagonistas "podem ser vistos como ciborgues, locomovendo-se por meio de artefatos tecnológicos", em formulação que remete a Donna Hawaway. Para a estadunidense (Haraway, 2001, p.40) o ciborgue trata-se de "um organismo cibernético, um híbrido de máquina e organismo, uma criatura de realidade social e também uma criatura de ficção"; ao que propõe, de maneira correlata, que "talvez os paraplégicos e outras pessoas seriamente afetadas possam ter (e algumas vezes têm) as experiências mais intensas de uma complexa hibridização com outros dispositivos de comunicação". Nesses termos, a desabilidade física, correlata ao isolamento de Marquim da Tropa, também pode ser interpretada como uma aproximação das tecnologias (o intenso e íntimo trabalho que realiza em sua rádio pirata), favorecendo o seu protagonismo na reviravolta final do longa-metragem.

Dimas Cravalanças, o viajante do tempo que busca provas de violência estatal contra a população da Ceilândia, ratifica essa toada subversiva via ficção-científica. Através de uma mensagem enviada do futuro para a sua nave, o assistimos descobrir que "o clima tá tenso" após à imprevista chegada da Vanguarda Cristã ${ }^{25}$ ao poder no tempo de onde veio. Sua missão é então abortada e ele é convocado para outra de urgência: "impedir a grande explosão", "um evento eletromagnético ocorrido no passado [que] ameaça o futuro da Terra". Trata-se da explosão de Brasília engendrada por Marquim da Tropa, Sartana, DJ Jamaika e outros. À vista disso, o agente terceirizado, descrente das lógica do Estado, assume o lado de Sartana e Marquim da Tropa. Nesses termos, o pessimismo frente à justiça estatal não expressa a incapacidade de ação por parte de Dimas Cravalanças, mas, em certo sentido, justamente a sua possibilidade de enfrentamento radical das forças estabelecidas através da subversão. Nessa reviravolta do personagem, o nome Dimas mostra-se signi-

25 A presença e força da Vanguarda Cristã no futuro de Cravalanças é uma referência à Frente Parlamentar Evangélica e Católica no Congresso Nacional, costumeiramente referida "bancada evangélica", em 2013 (ano em que o filme era realizado) a terceira mais expressiva numericamente no Congresso brasileiro. Seus posicionamentos, desde o governo do PT, vêm sistematicamente se dando contra iniciativas em prol dos direitos humanos, justamente aquelas como a missão de Cravalanças. Esta bancada, atualizada no futuro proposto pelo filme, indica a sobrevivência da grande influência religiosa de viés conservador na política brasileira, ao passo que o título "vanguarda" explicita o fito de aparência de renovação dessa lógica. 
ficativo: remete ao santo católico que foi crucificado junto a Jesus Cristo - Dimas, o bom ladrão -, que reconhece-se pecador já na cruz, sendo então perdoado e recebido no paraíso conforme o evangelho de Mateus. De forma semelhante, o personagem de Queirós assume de última hora o lado do "povo da Ceilândia", buscando à sua maneira a redenção. Para os Racionais $\mathrm{MC}^{26}$ - na música de Vida Loka II - Dimas seria o primeiro "vida loka".

Dimas Cravalanças, na reviravolta que o proíbe de voltar ao futuro até que impeça a grande explosão no passado, visita ilegalmente o tempo de onde veio, onde vemos breves imagens de uma Brasília dentre escombros, nublada, onde a aridez do planalto é de cores frias, povoada por ferros retorcidos. Esse espaço pode ser tratado como um método de análise do presente, sugerindo um rumo para onde a tecnologia e os desdobramentos diversos da modernidade/colonialismo levarão a sociedade. A bomba que explode no desfecho de Branco Sai, Preto Fica, diferente de reparar a violência sofrida pelos personagens (como era a missão de Dimas inicialmente), sublinha a centralidade da violência na relação entre a população do Distrito Federal. Ao mesmo tempo em que representa a possibilidade da superação das relações de poder postas até então através da penetração violenta do centro pela periferia (através dos sons e vozes que constituem essa bomba), essa forma de representação do futuro aponta para a impraticabilidade de redenção em uma perspectiva dialógica.

Branco Sai, Preto Fica é simultaneamente um tipo de denúncia da subordinação da Ceilândia em uma relação desigual com o centro quanto uma busca por valorização do universo cultural local dessa periferia, fabulando no mesmo universo dos sujeitos representados, em conjunto com eles. A ideia mesmo de "fabulação" é explicitada na conclusão do longa-metragem quando vemos num letreiro na tela: "da nossa memória fabulamos nois mesmos", evidenciando simultaneamente a hibridez entre características ficcionais e documentais no filme e a liberdade dramática concedida aos atores/ sujeitos representados. Ao passo em que o esgotamento dos avanços

26 A música faz parte do álbum de 2002 "Nada como um dia após o outro". Provavelmente o maior grupo de rap brasileiro, é lembrado em Rap, o canto da Ceilândia por sua passada pela Ceilândia e por citar a cidade em uma de suas músicas. 
sociais na lógica da política institucional é reafirmado na narrativa (já anteriormente afirmado de forma pulverizada nessa filmografia), as formas de financiamento e o reconhecimento de Branco Sai, Preto Fica apontam para um diálogo e cooperação entre grupos sociais marginalizados e poder público, pelo menos à época. Narrativamente, contudo, as possibilidades abertas a partir de estratégias ficcionais projetam um futuro onde se potencializa a precariedade em que se encontram os sujeitos representados. Nesses termos, ao vislumbrar a impossibilidade de reparação das violências do passado enquanto documentário, o filme se entranha cada vez mais, conforme ruma ao desfecho, no terreno da ficção. Oliveira e Maciel (2017, p.27) também já postularam de maneira acertada que o impasse apresentado na conclusão do filme "é que a incineração do passado [...] acontece sem que uma redefinição de um novo campo de intervenção e expectativa desponte no horizonte, posto que o futuro [...] não é outra coisa senão o próprio presente exagerado" (Idem., p.27).

\subsection{Era uma vez Brasília (2017)}

Em Era uma vez Brasilia, último filme de Queirós, somos apresentados a uma Ceilândia soturna, invariavelmente noturna, onde o ambiente sonoro é sutilmente povoado por urubus, cães raivosos, explosões, sirenes, helicópteros dentre outros elementos que a demarcam como um local perigoso. A trama do filme é que o agente intergaláctico WA4 - encarnado por Wellington Abreu - recebe a missão de vir para a Terra matar o presidente Juscelino Kubitscheck em 1959, no dia da inauguração de Brasília. Nativo do planeta do Sol Nascente e lá prisioneiro, WA4 foi sentenciado por construir uma casa em terras invadidas para a sua família. Sua missão vindo à Terra é a possibilidade para que possa prover aos familiares uma moradia legalizada. O planeta de onde vem WA4 não tem terra para toda a população, resultando em prisões, deportações e missões intergalácticas aos considerados "invasores". Se em Branco sai, preto fica o futuro em ruínas era um método de análise do presente, aqui o filme joga seu teor ficcional para outros planetas e galáxias, de forma que a trajetória de WA4 faz uma clara analogia com a história 
do povo ceilandense. Se antes viajava-se no tempo para explicar a nossa sociedade, agora viaja-se no tempo-espaço, esboçando uma cosmologia do controle.

Durante boa parte do filme estamos com esse agente em sua nave, em cenas de pouca ação e completo isolamento, retomando a sensação já vivenciada por Dildu em A cidade é uma só? ou pelos personagens de Branco sai, preto fica. A narrativa no entorno de WA4 - de certa forma como em A cidade é uma só? -, conecta os anos iniciais de Brasília ao presente: após o longo "primeiro ato" onde acompanhamos o viajante solitário, sua nave então perde-se no tempo e aterrissa - ou melhor, cai bruscamente - na Ceilândia de 2016, primeiro ano da presidência de Michel Temer.

Outros personagens no longa-metragem, habitantes dessa Ceilândia distópica, são Andreia - encarnada por Andreia Vieira, atriz não-profissional estreante nos filmes de Queirós -, ex-presidiária julgada por ter assassinado um homem que a assediou em um bar; e Marquim da Tropa. Ambos à margem da lei, são acuados por um radar/satélite estatal que os sonda ininterruptamente. Conhecem-se à noite em uma ponte metálica para pedestres, apresentada como um raro refúgio a essa monitoração, um ponto onde encontram-se insondáveis. Sua marginalidade frente à norma e controle estatal, portanto, os conecta. Essa ponte, justamente porque local de transição, encontra-se isenta da gerência dos mecanismos estatais, o que sublinha a relevância da fronteira socioespacial: a ênfase do controle mira a periferia.

Os personagens, nervosos, marginais/marginalizados e sempre sobre possível vigilância, fumam bastante, senão compulsivamente. Essa ação elíptica materializa a dificuldade de consolidação de formas de agenciamento por parte dos atores e diretor dentre o universo diegético proposto. O filme desenvolve temas recorrentes nas obras anteriores como viagem no tempo, violência e controle de Estado, periferia e negritude. Dentre as imagens, vemos perseguições de carro, controle policial, raps de protesto, prisioneiros sendo transportados entre Ceilândia e Brasília; momentos cujo encadeamento, contudo, consolida-se mais como um ensaio sobre a criação de um universo de Ceilândia distópica do que a busca por um encadeamento narrativo rigoroso. 
Para que compreendamos as nuances dessa diegese não basta pensar o espaço, mas sua intersecção com o tempo: o enguiço da ação dramática relaciona-se intimamente e explicitamente à tomada de poder de Michel Temer como presidente interino da República. Esse contexto é resgatado principalmente através de áudios de arquivo: a votação do Impeachment de Dilma Rousseff, pronunciamentos dela, de Temer, etc. Esse momento de ruptura, de encolhimento das alternativas político-institucionais, é comentado pelo atordoamento de personagens sem saída, pela formulação e exposição de um universo em caos. Exacerba-se a incerteza quanto às formas de mediação institucional, já colocadas de maneiras diversas em toda a sua obra. Os quase 100 minutos de duração desse filme estendem ao máximo essa gagueira arrebatada: é o mais longo e menos narrativo de Queirós.

\section{CONSIDERAÇÕES FINAIS}

Ao longo do artigo buscamos apreender na filmografia de Adirley Queirós a forma com que é representada a Ceilândia enquanto espaço físico e simbólico, e como ela é vivenciada pelos sujeitos plurais que nela habitam e por ela passam. A cidade figura nesses filmes como permeada por uma série de problemas mais ou menos comuns às periferias brasileiras, ainda que com toda a particularidade de ser fruto da segregação estatal e vivendo o paradoxo de ser simultaneamente vizinha de Brasília e carente das benesses do Estado. Temos em evidência nesse cinema os relatos de uma série de moradores locais que atrelam em suas narrativas os complexos impasses socioespaciais da história e do presente da Ceilândia à dimensão da segregação urbana, da racialização por parte do Estado e da violência policial correlata a esses fenômenos. Os personagens são representados como corpos e subjetividades em grande medida silenciados, esquecidos, e simultaneamente (paradoxalmente) vigiados, marcados. É o caso de Dimas Cravalanças, o ativista do futuro abandonado no tempo-espaço. Dildu, o político não eleito. Sartana e Marquim da Tropa, isolados em suas casas devido às deficiências adquiridas pela violência racista da sempre presente "policia do bem estar social" brasiliense. Nancy, que reprimiu, como muitos outros, 
seus sonhos de uma vida digna no Plano Piloto. Andreia e Marquim em Era uma vez Brasilia, concomitantemente excluídos pelo Estado e constantemente policiados pelo aparato repressivo estatal. Os rappers do primeiro filme de Queirós, que comentam os estereótipos ligados aos ceilandenses e a falta de representatividade das periferias na política institucional. Ou então os trabalhadores sem o devido reconhecidos em Dias de Greve e Fora de Campo.

$\mathrm{O}$ foco desse cinema nessas diversas situações existenciais documentadas ou "fabuladas" dentre o espaço da periferia mantém Brasília em um fora-de-campo constante. A capital se faz presente através dos relatos orais e de uma série de mecanismos impessoais de controle colocados principalmente nos dois últimos longa-metragens. A Ceilândia, "protagonista" desse conjunto de filmes, contudo, não existe de forma perene, mas como uma construção ativa: do rádio, da cultura popular e/ou black, das experiências em comum, da identificação racial e socioeconômica, de uma certa imaginação distópica em comum, tanto quanto do próprio controle estatal e de seus instrumentos que constantemente diferenciam e classificam os sujeitos. Esses sujeitos pulverizados, apresentados através de recortes diversos, constroem um mosaico de representações da/na Ceilândia, ora afastando-se e ora aproximando-se da pretensão documental.

A posição crítica, ostensiva a todos esses filmes, em $A$ cidade é uma só? materializa-se ao pôr em xeque as interpretações de uma série de documentários e cinejornais mobilizados como material de arquivo. Esses filmes prévios, cujo teor refere-se a uma base histórica comum entre os moradores da capital e do entorno brasiliense, são mobilizados de forma predominantemente irônica, contrapostos às leituras dos ceilandenses; desmonta-se assim o sentimento nacionalista, integrador e teleológico que inspirou Kubitscheck e o Plano Piloto.

Para além da crítica aos discursos dos cinejornais estatais, a potencialidade do uso dos procedimentos documentais em $A$ cidade é uma só?, Branco sai, preto fica e Era uma vez Brasília mostra-se ao fundir-se às perspectivas dos sujeitos representados acerca dos desdobramentos do passado no contemporâneo; servindo de base às intervenções criativas desses agentes no presente. Essas formas es- 
téticas propiciadas pela lente de Queirós potencialmente recompõe os circuitos de significados atribuídos à Ceilândia e aos ceilandenses, tanto através da (re)construção das memórias e experiências que marcam a história do grupo quanto através da ficcionalização dos espaços do presente e do futuro. Em Branco sai, preto fica e Era uma vez Brasília, obras em que elementos ficcionais mais enfaticamente tomam parte na construção do universo diegético, acessamos um ambiente que tanto no presente quanto no futuro se mostra distópico, de feições fantasmagóricas, projetando os sujeitos sobre cenários re -especulados que redimensionam suas possibilidades de ação e suas possibilidades de "eu"; formalizando justamente um cenário que entranha o material/histórico às subjetividades desses próprios agentes, pondo-os a debater-se com suas próprias ficções. Em Branco Sai, Preto Fica, assistimos com clareza ao longo da narrativa o trânsito entre as expectativas documentais acerca da violência policial na Ceilândia para as "fabulações" criadas pelos sujeitos denunciantes. A hipérbole das formas de controle nesses borram as expectativas de realismo fomentadas nos primeiros filmes; hipérboles que, ao passo em que nos afastam do regime documental, nos aproximam da crua realidade experimentada pelas populações subalternas da periferia.

O cinema, no pensamento de Stuart Hall (1996, p.75), tratase de "uma forma de representação capaz de nos construir como sujeitos e temas de novos tipos", com o potencial de desestabilizar e desessencializar formas de reconhecer o social, de propor outros modos de pensar e experimentar a vida em sociedade. Nos dois últimos filmes de Queirós as possibilidades legadas aos sujeitos de projetar a si mesmos em ambientes especulados, encarnando versões ciborgues de si mesmos, pairam significativamente em um jogo de potência e impotência. O universo diegético, contextualizado e construído em uma comunidade onde os efeitos da segregação Estatal são evidentes, é ficcionalizado de forma com que, em grande medida, reitera-se as dificuldades da ação. Nesses termos, a ficção reforça e reafirma o diagnóstico social cético ostensivo a todos os filmes de Queirós. Este diagnóstico proposto pela obra, contudo, não trata-se de uma reificação pessimista das possibilidades de ação: os filmes, enquanto objetos culturais extra-diegéticos, circulam as narrativas 
dos sujeitos envolvidos, suas possibilidades de expressão e mobilidade através do reconhecimento e debate que se dá no entorno dessa obra e dos temas e eventos por ela salientados.

\section{REFERÊNCIAS}

AUMONT, J.; MARIE, M. A Análise do filme. Lisboa: Texto \& Grafia, 2011.

BARONE, J. G. Assimetrias, dilemas e axiomas do cinema brasileiro nos anos 2000. Revista Famecos, Porto Alegre, v. 18, n.3., p. 916-932, 2011.

BRAH, A. Diferença, diversidade, diferenciação. Cadernos Pagu, Campinas, n. 26, p. 329-376, 2006.

CANTUARIA, A. C.; CHACON, C.; GUIMARÃES, V. L. O documentário que leva à vingança. Territórios Transversais, v.1, p. 30-32, 2015.

CODEPLAN. Perfil das pessoas com deficiência do Distrito Federal. 2013. Disponível em: https://bit.ly/2yvQVam. Acesso em: 14/7/19.

COSTA, S. Dois atlânticos. Belo Horizonte: Editora UFMG, 2006.

DALPIZZOLO, D. Entrevista com Adirley Queirós. Multiplot, 2012. Disponível em: https://goo.gl/MVsNNJ. Acesso em: 14/7/2019.

GOUVÊA, L. A capital do controle e da segregação Social. In PAVIANI, A. (Org.). A conquista da cidade. Brasília: Editora Universidade de Brasília, 1998. p. 75-96.

GUIMARÃES, A. S. A.. Classes, Raças e Democracia. São Paulo: Editora 34, 2002.

GUIMARÃES, C.; GUIMARÃES, V. Da política no documentário às políticas do documentário: notas para uma perspectiva de análise. Revista Galáxia, São Paulo, n. 22, p. 77-88, 2011.

HALL, S. Quem precisa de identidade? In: SILVA, T. (Org.). Identidade e diferença: a perspectiva dos estudos culturais. $15^{\mathrm{a}}$. ed, Petrópolis: Vozes, 2014. p. 103-131.

HALL, S. Identidade cultural e diáspora. Revista do Patrimônio Histórico e Artístico Nacional, Rio de Janeiro, n. 24, p. 68-75, 1996.

HOLSTON, J. A cidade modernista: uma crítica de Brasília e sua utopia. São Paulo: Companhia das Letras, 1993.

ISAIAS, H. R. O cinema é um só?: montagem e desmontagem em Adirley Queirós. 2017. 128 p. Dissertação (Mestrado em Comunicação) 
A representação da Ceilândia e dos ceilandenses no cinema de Adirley Queirós.

Universidade Federal do Ceará, Programa de Pós-Graduação em Comunicação, Fortaleza/CE, 2017.

LIMA, T. H. A. Imagens táticas contra utopia modernista: investigando as primeiras imagens de Brasília e A cidade é uma só? Revista Lumina, v. 10, n. 2, 2016. Disponivel em: https://bit.ly/2LTpOxe. Acesso em: 14/7/19.

MESQUITA, C. Memória contra utopia: Branco sai, preto fica (Adirley Queirós, 2014). In: Encontro da Associação Nacional dos Programas de Pós-Graduação em Comunicação (COMPÓS), Brasília. Anais. 2015.

MOBILIZE BRASIL. Campanha calçadas do Brasil: relatório final da campanha e estudo realizado pelo Mobilize Brasil. 2013. Disponível em: https://bit.ly/2sl1LN3. Acesso em: 13/7/19.

NICHOLS, B. Introduction do documentary. Bloomington, Indiana: Indiana University Press, 2010.

OLIVEIRA, T. B.; MACIEL, D. E. F. Cultura e revanche na guerra social: comentários sobre Branco sai, preto fica, de Adirley Queirós. Rev. Inst. Estud. Bras, n. 68, 2017. Disponivel em: https:// bit.ly/2xLSMXN. Acesso em: 14/7/2019. DOI: http://dx.doi. org/10.11606/issn.2316-901x.v0i68p12-31.

PINTO, I. A Brazilian Bomb in Cartagena. In: Fipresci - The International Federation of Film Critic. 2015. Disponível em: goo.gl/dmYvCd. Acesso em: 12/02/19.

PISCITELLI, A. Interseccionalidade, categorias de articulação e experiências de migrantes brasileiras. Sociedade e Cultura, Goiás, v. 11, n. 2, p. 263-274, 2008.

RESTREPO, E. Antropología y estudios culturales. Argentina: Siglo Veintiuno, 2012.

RIDENTI, M. Artistas e intelectuais no Brasil pós-1960. Tempo Social, São Paulo, v. 17, n. 1, p. 81-110, 2005.

SABOIA, L.; SANDOVAL, L. “A cidade é uma só?”: luta por reconhecimento na relação centro-periferia em Brasília. In: Seminário Internacional Urbicentros, III, Bahia: Salvador. Anais. 2012.

SINHORETTO, J. et al. A filtragem racial na seleção policial de suspeitos: segurança pública e relações raciais. In: LIMA, C. P.; BAPTISTA, G. C.; FIGUEIREDO, I. S. (Org.). Segurança pública e direitos humanos: temas transversais. Brasília: Ministério da Justiça, 2014. p. $121-160$. 
STAM, R. Introdução à teoria do cinema. $5^{\mathrm{a}}$. ed. Campinas: Papirus, 2013.

SUPPIA, A. Acessos restritos: Branco Sai, Preto Fica (2014), de Adirley Queirós, e o cinema brasileiro de ficção científica contemporâneo. Revista Hélice, Espanha, vol. 2, n. 5, p. 21-29, 2015.

SUPPIA, A.; GOMES, P. Por um cinema infiltrado: entrevista com Adirley Queirós e Maurílio Martins a propósito de Branco Sai, Preto Fica (2014). Doc On-line, n. 18, 2015. Disponível em: https://bit. ly/32qngwD. Acesso em: 14/7/2019. DOI: 10.20287/doc.d18.dt17.

VANOYE, F.; GOLIOT-LÉTÉ, A. Ensaio sobre a análise fílmica. $2^{\mathrm{a}}$. ed. Campinas: Papirus. 2002.

VIGOYA, M. V. Género raza y nación: los réditos políticos de la masculinidad blanca en Colombia. Maguré, Bogotá, v. 27, p. 71104, 2013.

WILLIAMS, R. Marxismo e Literatura. Rio de Janeiro: Zahar, 1979. 
